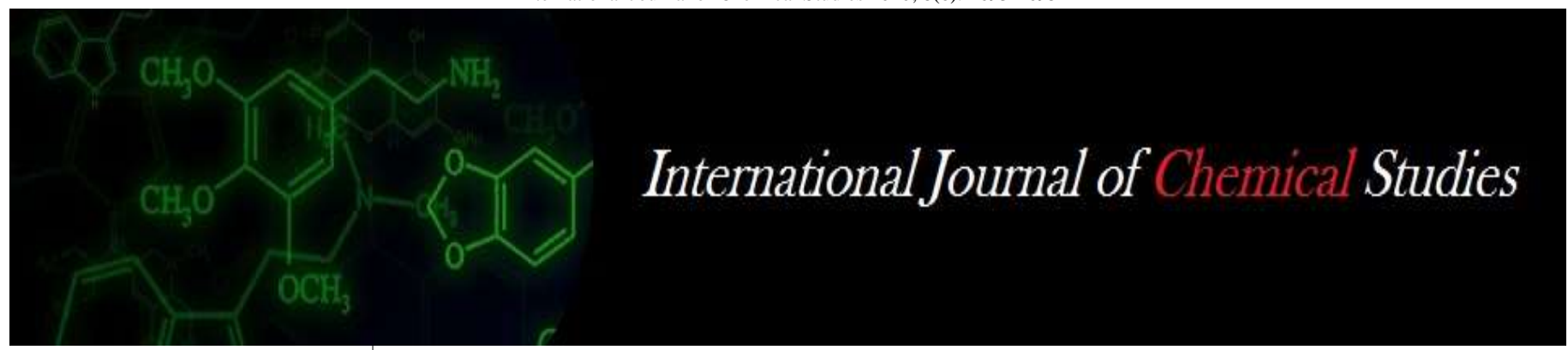

P-ISSN: 2349-8528

E-ISSN: 2321-4902

www.chemijournal.com

IJCS 2020; 8(6): 1693-1695

(C) 2020 IJCS

Received: 17-09-2020

Accepted: 01-11-2020

\section{Lokhande NR}

College of Agriculture,

Vasantrao Naik Marathwada

Krishi Vidyapeeth, Latur,

Maharashtra, India

Bangar HV

College of Agriculture,

Vasantrao Naik Marathwada

Krishi Vidyapeeth, Latur,

Maharashtra, India

Kadhavane SR

College of Agriculture,

Vasantrao Naik Marathwada

Krishi Vidyapeeth, Latur,

Maharashtra, India

\section{Karde RY}

College of Agriculture,

Vasantrao Naik Marathwada

Krishi Vidyapeeth, Latur,

Maharashtra, India
Corresponding Author:

Lokhande NR

College of Agriculture,

Vasantrao Naik Marathwada

Krishi Vidyapeeth, Latur,

Maharashtra, India

\section{Influence of different organic manures on seed and oil yield and economics of sesame (Sesamum indicum $\mathbf{L}$.)}

\author{
Lokhande NR, Bangar HV, Kadhavane SR and Karde RY
}

DOI: https://doi.org/10.22271/chemi.2020.v8.i6x.11012

\begin{abstract}
A field experiment was conducted during kharif season of 2019-20 at Farm of Agronomy Section, College of Agriculture, Latur to find out the influence of different organic manures on growth and yield attributes of sesame. The experiment was laid out in a Randomized Block Design with nine treatments and replicated three times. The treatments were $\mathrm{T}_{1}$-Control, $\mathrm{T}_{2}-100 \% \mathrm{~N}$ (Urea), $\mathrm{T}_{3}-75 \% \mathrm{~N}$ (Urea) $+25 \% \mathrm{~N}$ $(\mathrm{FYM}), \mathrm{T}_{4}-75 \% \mathrm{~N}$ (Urea) $+25 \% \mathrm{~N}$ (Vermicompost), $\mathrm{T}_{5}-75 \% \mathrm{~N}$ (Urea) $+25 \% \mathrm{~N}$ (Poultry manure), $\mathrm{T}_{6}-$ $75 \% \mathrm{~N}($ Urea $)+25 \% \mathrm{~N}$ (Neem cake), $\mathrm{T}_{7}-75 \% \mathrm{~N}($ Urea $)+25 \% \mathrm{~N}$ (Karanj cake), $\mathrm{T}_{8}-75 \% \mathrm{~N}$ (Urea) $+25 \% \mathrm{~N}$ (Castor cake) and $\mathrm{T}_{9}-75 \% \mathrm{~N}$ (Urea) + Azotobactor. Application of $75 \% \mathrm{~N}$ through (Urea) $+25 \% \mathrm{~N}$ through (Poultry manure) ( $\left.\mathrm{T}_{5}\right)$ resulted in maximum seed yield $\left(516 \mathrm{~kg} \mathrm{ha}^{-1}\right)$, oil content $(48.67 \%)$ and oil yield $\left(251 \mathrm{~kg} \mathrm{ha}^{-1}\right)$. Maximum gross monetary return ( $\left.₹ 51642 \mathrm{ha}^{-1}\right)$, net monetary return ( $\left.₹ 29106 \mathrm{ha}^{-1}\right)$, cost of cultivation (₹ $22536 \mathrm{ha}^{-1}$ ) and B:C ratio (2.29) were also obtained due to application of $75 \% \mathrm{~N}$ through (Urea) $+25 \% \mathrm{~N}$ through (Poultry manure) $\left(\mathrm{T}_{5}\right)$.
\end{abstract}

Keywords: INM, oil content, oil yield, organic manures, RBD, sesame, seed yield

\section{Introduction}

Sesamum (Sesamum indicum L.) is an important oilseed crop of India belongs to family Pedaliaceae and the genus Sesamum. Sesame is also known as queen of oil seeds. It has about 50 per cent oil content. The sesamum oil contains oleic acid (47\%), linoleic acid (39\%), omega 6 fatty acids and highest ferric reducing antioxidant power (FRAP) value.

The important countries producing sesame are India, China, Japan, Sudan, Mexico, Turkey, Myanmar and Pakistan. In India, the major sesame growing states are Uttar Pradesh, Rajasthan, Madhya Pradesh, Andhra Pradesh, Maharashtra, Gujarat, Tamil Nadu and Odisha. In Maharashtra, the important districts growing this crop are Jalgaon, Nashik, Dhule, Pune and Solapur. Area under sesame in India was 18-20 lakh ha with the production of 6.6 lakh metric tonnes during 2017-18. In Maharashtra, the total area under sesamum was 0.18 lakh ha with the production of 0.042 lakh tonnes having productivity $233 \mathrm{~kg} \mathrm{ha}^{-1}$. (Anonymous, 2017-18) [1].

Sesame is a robust crop that grows in drought conditions, in high heat, with residual moisture in soil after monsoons are gone or even when rains fail or when rains are excessive. It is a crop that could be grown by subsistence farmers at the edge of deserts, where no other crops can grow, so it has been called a survivor crop.

Addition of vermicompost to soil improves the chemical and biological properties of soil and thereby improves its fertility. Poultry manure has been recognized as the most desirable organic manure in sesame. It improves soil fertility by adding $\mathrm{N}$ and $\mathrm{P}$ as well as micronutrients and improves moisture and nutrient retention (Farhad et al., 2009) ${ }^{[2]}$. Use of FYM has been found to enhance the crop yields by improving physical and biological properties of soil and increasing water holding capacity of soil. Azotobactor has the ability to fix atmosphere nitrogen and to make it available to the plants. Neem seed cake (Azadirachta indica), when added to the soil, increases the yield of crops on the long term, an excellent soil conditioner and has no negative effect on the environment (Lokanadhan et al., 2012) ${ }^{[3]}$. Karanj cake and castor cake are rich source of N, P, K which on application increase soil fertility and residual effect. 
Keeping in view of the beneficial effects of the organic manures, field experiment was carried out to study the effect of organic manures on seed and oil yield and economics of sesame.

\section{Materials and Methods}

The field experiment was conducted during kharif season of 2019-20, at Farm of Agronomy Section, College of Agriculture, Latur (Maharashtra). The soil of experimental plot was clayey in texture with chemical composition such as low in available nitrogen (121.3 $\left.\mathrm{kg} \mathrm{ha}^{-1}\right)$, medium in available phosphorous (18.57 kg ha $\mathrm{kg}^{-1}$ ) and very high in available potassium (499.9 $\left.\mathrm{kg} \mathrm{ha}^{-1}\right)$. The soil was moderately alkaline in reaction having $\mathrm{P}^{\mathrm{H}}(7.7)$ and containing very low organic carbon $(0.85 \%)$. The experiment was laid out in Randomized Block Design with nine treatments and replicated three times. The treatments were $\mathrm{T}_{1}$-Control, $\mathrm{T}_{2}-100 \% \mathrm{~N}$ (Urea), $\mathrm{T}_{3}-75 \% \mathrm{~N}$ $($ Urea $)+25 \% \mathrm{~N}(\mathrm{FYM}), \mathrm{T}_{4}-75 \% \mathrm{~N}$ (Urea) $+25 \% \mathrm{~N}$ (Vermicompost), $\mathrm{T}_{5}-75 \% \mathrm{~N}$ (Urea) $+25 \% \mathrm{~N}$ (Poultry manure), $\mathrm{T}_{6}-75 \% \mathrm{~N}$ (Urea) $+25 \% \mathrm{~N}$ (Neem cake), $\mathrm{T}_{7}-75 \% \mathrm{~N}$ (Urea) + $25 \% \mathrm{~N}$ (Karanj cake), $\mathrm{T}_{8}-75 \% \mathrm{~N}$ (Urea) $+25 \% \mathrm{~N}$ (Castor cake) $\mathrm{T}_{9}-75 \% \mathrm{~N}$ (Urea) + Azotobactor. A popular sesame variety in the region, JLT-408 was used in the study. Seeds of the sesame were sown on 2 August, 2019 in the rows spaced $45 \times 15 \mathrm{~cm}^{2}$. 2-4 seeds were dibbled at each hill at about 2 $\mathrm{cm}$ depth. Nitrogen and phosphorous were applied as per treatment through urea and SSP. Farm yard manure (FYM), vermicompost, poultry manure, karanj cake, castor cake and neem cake were applied as per treatments and mixed thoroughly in to the soil after layout. Various intercultural operations and plant protection measures were undertaken to improve the growth and yield of crops. The crop was harvested on $27^{\text {th }}$ October 2019 by cutting to the ground level with the help of sickle.

\section{Results and discussion 3.1 Quality attributes}

The mean oil content did not differ significantly due to different treatments. Highest oil content $(48.67 \%)$ (Table 1) was obtained with application of $75 \% \mathrm{~N}$ (Urea) $+25 \% \mathrm{~N}$ (Poultry manure) $\left(\mathrm{T}_{5}\right)$ which was closely followed by the treatment of $75 \% \mathrm{~N}$ (Urea) $+25 \% \mathrm{~N}$ (Vermicompost) $\left(\mathrm{T}_{4}\right)$.

Significantly higher oil yield $\left(251 \mathrm{~kg} \mathrm{ha}^{-1}\right)$ (Table 1) was produced due to application of $75 \% \mathrm{~N}$ (Urea) $+25 \% \mathrm{~N}$ (Poultry manure) $\left(\mathrm{T}_{5}\right)$ which was closely followed by the treatment of $75 \% \mathrm{~N}$ (Urea) $+25 \% \mathrm{~N}$ (Vermicompost) $\left(\mathrm{T}_{4}\right)$. This might be happened due to the higher oil content in seed. The higher oil extracted ultimately from higher seed yield. This result is in the line of Paul et al. (2017) ${ }^{[4]}$.

\subsection{Yield and yield attributes}

The seed yield of sesame was differed significantly due to different treatments. The maximum seed yield $\left(516 \mathrm{~kg} \mathrm{ha}^{-1}\right)$ was produced by the application of $75 \% \mathrm{~N}$ (Urea) $+25 \% \mathrm{~N}$ (Poultry manure) $\left(\mathrm{T}_{5}\right)$. The result is in confirmity with the results of Singh et al. (1997) ${ }^{[5]}$

The higher straw (3004 $\left.\mathrm{kg} \mathrm{ha}^{-1}\right)$ biological yield $(3521 \mathrm{~kg}$ ha $\left.{ }^{1}\right)$ (Table 1) was produced due to the application of $75 \% \mathrm{~N}$ (Urea) $+25 \% \mathrm{~N}$ (Poultry manure) $\left(\mathrm{T}_{5}\right)$. This increase in seed yield, straw yield and biological yield may be because of poultry manure has been known to help in reducing the soil $\mathrm{pH}$ to some extent by producing organic acids while their decomposition cause greater availability and mobility of nutrients mainly of micronutrients.

Application of $75 \% \mathrm{~N}$ (Urea) $+25 \% \mathrm{~N}$ (Poultry manure) $\left(\mathrm{T}_{5}\right)$ recorded maximum harvest index $(14.67 \%)$ (Table 1), which was closely followed by the treatment of $75 \% \mathrm{~N}$ (Urea) $+25 \%$ $\mathrm{N}$ (Vermicompost) $\left(\mathrm{T}_{4}\right)$.

Table 1: Influence of organic manures on oil content, oil and seed yield, straw and biological yield and harvest index of sesame

\begin{tabular}{|c|c|c|c|c|c|c|}
\hline Treatment & $\begin{array}{c}\text { Oil content } \\
(\%)\end{array}$ & $\begin{array}{l}\text { Oil yield } \\
\left(\mathrm{kg} \mathrm{ha}^{-1}\right)\end{array}$ & $\begin{array}{c}\text { Seed yield } \\
\left(\mathrm{kg} \mathrm{ha}^{-1}\right)\end{array}$ & $\begin{array}{c}\text { Straw yield } \\
\left(\mathrm{kg} \mathrm{ha}^{-1}\right)\end{array}$ & $\begin{array}{c}\text { Biological yield } \\
\left(\mathrm{kg} \mathrm{ha}^{-1}\right)\end{array}$ & $\begin{array}{c}\text { Harvest index } \\
(\%)\end{array}$ \\
\hline $\mathrm{T}_{1}$-Control & 45.36 & 149 & 328 & 2253 & 2581 & 12.61 \\
\hline $\mathrm{T}_{2}-100 \% \mathrm{~N}$ (Urea) & 47.52 & 165 & 343 & 2315 & 2658 & 12.72 \\
\hline $\mathrm{T}_{3}-75 \% \mathrm{~N}($ Urea $)+25 \% \mathrm{~N}(\mathrm{FYM})$ & 47.71 & 168 & 347 & 2407 & 2755 & 12.91 \\
\hline $\mathrm{T}_{4}-75 \% \mathrm{~N}$ (Urea)+ 25\% N (Vermicompost) & 48.51 & 229 & 481 & 2932 & 3413 & 14.09 \\
\hline $\mathrm{T}_{5}-75 \% \mathrm{~N}($ Urea $)+25 \% \mathrm{~N}$ (Poultry manure) & 48.67 & 251 & 516 & 3004 & 3521 & 14.67 \\
\hline $\mathrm{T}_{6-}-75 \% \mathrm{~T}_{6}-75 \% \mathrm{~N}($ Urea $)+25 \% \mathrm{~N}$ (Neem cake) & 47.76 & 183 & 379 & 2490 & 2868 & 13.20 \\
\hline $\mathrm{T}_{7}-75 \% \mathrm{~N}($ Urea $)+25 \% \mathrm{~N}($ Karanj cake $)$ & 48.26 & 204 & 418 & 2572 & 2990 & 13.63 \\
\hline $\mathrm{T}_{8}-75 \% \mathrm{~N}$ (Urea) + 25\% N (Castor cake) & 48.18 & 192 & 403 & 2562 & 2965 & 13.60 \\
\hline T9-75\% N (Urea) + Azotobactor & 48.35 & 205 & 429 & 2716 & 3145 & 13.99 \\
\hline SE+ & 1.17 & 12 & 27 & 143 & 146 & - \\
\hline $\mathrm{CD}$ at $5 \%$ & NS & 35 & 82 & 429 & 437 & - \\
\hline
\end{tabular}

\subsection{Economics}

Application of different organic manures significantly influenced gross monetary return. Significantly highest gross monetary return (₹ 51642 ha $^{-1}$ ) (Table 2) was obtained with the application of $75 \% \mathrm{~N}$ (Urea) $+25 \% \mathrm{~N}$ (Poultry manure) $\left(\mathrm{T}_{5}\right)$. This might be due to higher seed obtained with the $75 \% \mathrm{~N}$ (Urea) $+25 \% \mathrm{~N}$ (Poultry manure) $\left(\mathrm{T}_{5}\right)$ resulted in higher gross monetary return. This result is similar with Haruna and Aliyu (2012) ${ }^{[6]}$.

Application of different organic manures significantly influenced net monetary return. Significantly highest net monetary return (₹ $29106 \mathrm{ha}^{-1}$ ) (Table 2) was recorded with the treatment of $75 \% \mathrm{~N}$ (Urea) $+25 \% \mathrm{~N}$ (Poultry manure) $\left(\mathrm{T}_{5}\right)$. It may happened due to higher gross monetary return and comparatively no much higher cost of cultivation. These results are in confirmity with the results of Singh et al. (1997) [5].
The higher cost of cultivation ( $₹ 22536 \mathrm{ha}^{-1}$ ) and B:C ratio (2.29) (Table 2) was noticed due to application of $75 \% \mathrm{~N}$ (Urea) $+25 \% \mathrm{~N}$ (Poultry manure). This may be due to higher gross return and comparatively no much more cost of cultivation.

\section{Conclusion}

Application of $75 \% \mathrm{~N}$ through (Urea) $+25 \% \mathrm{~N}$ through (Poultry manure) $\left(\mathrm{T}_{5}\right)$ resulted in maximum oil content $(48.67 \%)$, seed $\left(516 \mathrm{~kg} \mathrm{ha}^{-1}\right)$ and oil yield $\left(251 \mathrm{~kg} \mathrm{ha}^{-1}\right)$, straw (3004 $\left.\mathrm{kg} \mathrm{ha}^{-1}\right)$ and biological yield (3521 kg ha-1) and harvest index $(14.67 \%)$. While, maximum gross monetary return (₹ 51642 ha $^{-1}$ ), net monetary return ( $₹ 29106$ ha $^{-1}$ ), cost of cultivation (₹ $22536 \mathrm{ha}^{-1}$ ) and B:C ratio (2.29) were obtained due to application of $75 \% \mathrm{~N}$ through (Urea) $+25 \% \mathrm{~N}$ through (Poultry manure) $\left(\mathrm{T}_{5}\right)$. 
Table 2: Influence of organic manures on seed yield, gross monetary return, net monetary return, cost of cultivation and B:C ratio of sesame

\begin{tabular}{|c|c|c|c|c|c|}
\hline Treatment & Seed yield $\left(\mathrm{kg} \mathrm{ha}^{-1}\right)$ & GMR (₹ ha-1) & NMR (₹ ha' $\left.\mathbf{~}^{-1}\right)$ & Cost of cultivation (₹ ha-1) & B:C ratio \\
\hline $\mathrm{T}_{1}$-Control & 328 & 32840 & 12693 & 20147 & 1.63 \\
\hline $\mathrm{T}_{2}-100 \% \mathrm{~N}$ (Urea) & 343 & 34300 & 14058 & 20299 & 1.68 \\
\hline $\mathrm{T}_{3}-75 \% \mathrm{~N}($ Urea $)+25 \% \mathrm{~N}(\mathrm{FYM})$ & 347 & 34743 & 14101 & 20485 & 1.69 \\
\hline $\mathrm{T}_{4}-75 \% \mathrm{~N}$ (Urea)+ 25\% N (Vermicompost) & 481 & 48086 & 26619 & 21467 & 2.23 \\
\hline $\mathrm{T}_{5}-75 \% \mathrm{~N}($ Urea $)+25 \% \mathrm{~N}$ (Poultry manure) & 516 & 51642 & 29106 & 22536 & 2.29 \\
\hline $\mathrm{T}_{6}-75 \% \mathrm{~T}_{6}-75 \% \mathrm{~N}($ Urea $)+25 \% \mathrm{~N}$ (Neem cake) & 379 & 37860 & 17072 & 20788 & 1.82 \\
\hline $\mathrm{T}_{7}-75 \% \mathrm{~N}($ Urea $)+25 \% \mathrm{~N}($ Karanj cake $)$ & 418 & 41831 & 21020 & 20812 & 2.00 \\
\hline $\mathrm{T}_{8}-75 \% \mathrm{~N}$ (Urea) $+25 \% \mathrm{~N}$ (Castor cake) & 403 & 40335 & 19530 & 20806 & 1.93 \\
\hline $\mathrm{T}_{9}-75 \% \mathrm{~N}($ Urea $)+$ Azotobactor & 429 & 42860 & 21608 & 21252 & 2.01 \\
\hline SE+ & 27 & 2724 & 2724 & - & - \\
\hline $\mathrm{CD}$ at $5 \%$ & 82 & 8166 & 8166 & - & - \\
\hline
\end{tabular}

\section{References}

1. Anonymous. Report on Oilseeds Division. Department of Agriculture, Cooperation and Farmers Welfare, Ministry of Agriculture and Farmers Welfare, Government of India, 2017.

2. Farhad W, Saleem MF, Cheema MA, Hammad HM. Effect of poultry manure levels on the productivity of spring maize (Zea maize L.). The Journal of Animal and Plant Science 2009;19(3):122-125.

3. Lokanadhan S, Muthukrishnan P, Jeyaraman S. Neem products and their agricultural applications. Journal Biopest 2012;5:72-76.

4. Paul A, George N, Chemining WA, Richard N, Michael A. Effect of organic manures on nutrient uptake and seed quality of sesame. Journal of Agricultural Science 2017;9(7). E-ISSN 1916-9760.

5. Singh GR, Parihar SS, Chaure NK, Choudhary KK, Sharma RB. Integrated nutrient management in summer sesame (Sesamum indicum L.). Indian Journal of Agronomy 1997;42(4):699-701.

6. Haruna IM, Aliyu L. Seed yield and economic returns of sesame (Sesamum indicum L.) as influenced by poultry manure, nitrogen and phosphorus fertilization at Samaru, Nigeria. Revista Científica UDO Agrícola 2012;12(1):152-156. 